\title{
The Impacts of Standards on the Economic Growth in Construction Industry with the Example of China
}

\author{
Bowen $\mathrm{Xu}^{*}$ \\ International Business school \\ Yunnan University of Finance and \\ Economics \\ Kunming, China \\ 1005745234@qq.com
}

\author{
Qifa Jiang \\ International Business School \\ Yunnan University of Finance and \\ Economics \\ Kunming, Yunnan \\ fagenjiang3@163.com
}

\author{
Wenfang Sun \\ International Business School \\ Yunnan University of Finance and \\ Economics \\ Kunming, Yunnan \\ 1138359402@qq.com
}

\begin{abstract}
Construction plays a key role in an economy, hence it is of critical importance to push this industry for developing countries suffered by under development. This paper introduces a good example of China in which standards are continuously implemented so as to quickly promote industrial competitiveness in construction section. The authors use the extended CobbDouglas production function to testify the relationship between engineering standards and the economic growth in construction industry. The results explain that engineering standards have a significantly positive effect on construction economy when based on the data between 1995 and 2016. A 1\% additional capital investment will increase $0.182 \%$ output in construction, in contrast with the fact that $1 \%$ standard change will stimulate $\mathbf{0 . 9 3 3 \%}$ output in this section. Construction standards have a strong driving force in the economy, which can supply some enlightenment for other developing countries.
\end{abstract}

Keywords: engineering construction standard, construction economy, production function

\section{INTRODUCTION}

As one of pioneering industries, construction plays a key role in an economy, partly because its output is large and therefore that it is a significant part of the economy, and partly because it can supply many employments to the economy as well. Therefore, it is a good policy to expand construction industry for developing countries. Yet the thing might be very difficult in these countries due to lack of capital and skilled labor, which are critical inputs to grow industries and an economy according to traditional economic theories. A good example is China's construction. Just in 40 years, China's construction companies have grown so competitively that there are 27 firms which are listed in ENR's 2019 Top 100 International Contractors. Comparing with other developing countries in the same situation that there is inefficient money, the practice continuously in China is that many engineering standards have been enacted to regulate firms and finally push up construction competitiveness very quickly. By July 4, 2019, China has 1983 effective mandatory national standards and 34,442 recommended national standards, 4,562 of which were in the national engineering construction standard system and 2021 to be compiled [1]. Why and how can standards exert impacts on the growth in construction section? Is there any policy suggested for other developing countries? The relevant issues should be carefully analyzed.

\section{LITERATURE REVIEW}

\section{A. Benefits of standards in an economy}

In general, the economic benefits brought by standardization mean that reasonable and effective standards can effectively promote enterprises to improve technology and management, improve labor productivity of the whole society, optimize resource allocation, and promote healthy economic development [2]. In addition, standard can accelerate technological diffusions, eliminate outdated products, reduce market entry risks, lower R\&D costs, cut off monopoly, increase international competitiveness, and conclude a virtuous cycle of market expansion [3]. Moreover, standards will benefit both producers and consumers, and trigger a price competition among counterpart firms so as to bring about economies of scale on the demand side [4]. Considering global market, standards can effectively protect the domestic market, meanwhile weaken foreign companies' competitiveness. Further, when a firm can make its technical standards dominant in implementation in the international market, the firm can achieve market power and partly monopolize the products, so as to gain the excess profit [5].

Developed countries have long recognized that standards can promote the economic growth [6]. Since the policies and economic fundamentals are different, the promotion will vary among countries. For example, standards have a $0.9 \%$ expansionary effect on the economy in Germany [7], yet just a $0.05 \%$ net effect in UK [8].

In China, some researchers have analyzed the net effect of standards on the economy. Most researchers will apply the Cobb-Douglas Production Function in their models, yet the final results differ greatly because of different data. Liu Zhengang collects the standards data from 1990 to 2002 and shows a $4.8 \%$ effect, Yu Xinli presents a $0.79 \%$ effect based on the recent 30 years data [9] [10]

It is sufficient evidence that standards will exert distinct impacts on various industries. Lots of researches depict that various industries have different willingness to exercise

*Corresponding author 
standardization. Manufacturing industries have the strongest willingness to practice standards due to its preference for social division of labor, while service industries have lower willingness to implement standards because of being knowledge-intensive [11]. When taking account of international trade, Peter Swann used the traditional General Equilibrium Model and Partial Equilibrium Theory to analyze the relationship between global standards and international trade, and then concluded that standards in the field of agriculture and development would have a negative impact on international trade, while standards in the field of industry and innovation would exert a positive impact on trade [12].

\section{B. Units Benefits of engineering standards in industry and economy}

In terms of construction industry, how will construction standards push the economic growth? And how will standards grow economic output in this industry? The conclusions are different on account of research methods. Wang Chao established the Calculable General Equilibrium Model (CGE) by combining Social Accounting Matrix (SAM), Production Function Method, Input-output method and other methods to calculate the economic benefit from construction standardization and concluded that its benefit is $0.4 \%$ [13]. Based on the Regression Analysis of production function at the micro and macro levels, Wu Xudan empirically analyzed the stock of Chinese standards from 1992 to 2008 as an independent variable, and the results tell us that the elasticity coefficient of construction standards is 0.28 [14]. Liang Xiaozhen used the accurate data from 1978 to 2006 and analyzed the relationship between construction standards and economic growth by using Co-integration Theory and adopted the theory into the production function, arrived at the final results that the growth rate of construction standards pushing GDP is $0.222 \%$ [15]. However, little research focuses on the impacts of construction standards on the industrial economy.

\section{Model establishment AND DATA COLleCtion}

\section{A. The model}

Generally, we can adopt the Cobb-Douglas Production Function to analyze the effects of standards on economic growth, as in (1).

$$
G_{t}=A_{t} K_{t}^{\alpha} L_{t}^{\beta}
$$

Here, $G_{t}, K_{t}$ and $L_{t}$ represent economic output, capital and labor in t times, respectively. The exponents of $\alpha, \beta$ represent the price elasticity of capital and labor, the sum of the two is the output elasticity of production function.

A represents an efficiency parameter, called Total Factor Productivity (TFP) and reflecting the technical progress, and will be brought into the production function.

If the Equation (1) is expressed in logarithmic form, then we can get the following equation:

$$
\operatorname{Ln} G_{t}=a+\operatorname{Ln} A_{t}+\alpha \operatorname{Ln} K_{t}+\beta \operatorname{Ln} L_{t}
$$

Typically, when taking account of the effects of standards and innovations on technical progress, A, we will select the indicators as patents, imported techniques and standards, etc [16]. Yet being a slow-cycle market, construction has characteristics which includes that techniques in this industry will change not so fast, and technical progress of this industry will mainly be indicated by standards rather than by patents [17]. Therefore, to simplify the question, we can have the equation (3) when technical progress, A, by construction standards:

$$
\operatorname{Ln} G_{t}=a+\operatorname{Ln} S_{t}+\alpha \operatorname{Ln} K_{t}+\beta \operatorname{Ln} L_{t}
$$

Here $S_{t}$ represents standards in $t$ time.

\section{B. The data}

Based on the above formula (3), this paper will use traditional Cobb-Douglas Production Function and build a model to describe the GDP growth. Using by Gross Domestic Construction Product in China, engineering standards, construction employments, and fixed assets investment in construction to indicate standard input(S), labor input(L), capital investment $(\mathrm{K})$, industrial gross output $(\mathrm{G})$, respectively, so that we can analyze the effects of standards on economic growth in construction section.

We select the sum of national standards, industrial standards and industrial association standards adopted in construction industry, which are listed in the gazette, Standards Catalogue of the People's Republic of China in Construction Industry (2016), to be the indicators of construction standards. Since regional standards show some characteristics of instability, they are exclusive of the final indicators.

Hence, the statistical formula of construction standards [9] is defined as following:

$$
\operatorname{STD}(t)=\sum_{i=0}^{t} \mathrm{P}(i)-\sum_{i=0}^{t} W(i)
$$

Where, $\operatorname{STD}(\mathrm{t})$ represents the effective standard stock at the deadline point $\mathrm{t}$; $\mathrm{P}(\mathrm{i})$ is the number of standards issued in year $\mathrm{i}$; $\mathrm{W}(\mathrm{i})$ is the number of standards abolished in the ith year.

Economic growth in construction industry will be measured by Gross Domestic Construction Product (GDCP). We will adopt real outputs in this industry. Using the Consumer Price Index (CPI) to deflate the price factor, taking the year of 1995 as the base year, then the real output can be calculated via output in current price divided by CPI. Employments in construction will be measured by the number of employees in construction enterprises, and the fixed assets investment will be directly based on the investment in fixed assets in construction (excluding farmers).

In order to eliminate time series heteroscedasticity and make its trend linearized, natural logarithm transformation will be carried out on variables, and the total output value of domestic construction industry, standard stock in construction, number of employees in construction enterprises and investment in fixed assets in construction industry will be denoted by $\operatorname{Ln} G$ 、 $\operatorname{Ln} S 、 \operatorname{Ln} L 、 \operatorname{Ln} K$, respectively, as shown in the formula (3). The data adopted in this paper will be collected annually and based on the period between 1995 
and 2016. The data are officially collected from the website of the National Bureau of Statistics of China (http://www.stats.gov.cn/) and Standards Catalogue of the People's Republic of China in Construction Industry (2016).

\section{EMPIRICAL ANALYSIS}

\section{A. Inference test}

The results of calculations are expressed as following when based on the above formula (3) and using the four corresponding data sets in construction industry with the help of Eviews software:

\section{$L N G$}

\section{$0.911819+0.364995 L N K+0.243719 L N L+$ $0.539942 \mathrm{LNS}$}

$$
\begin{gathered}
s=(1.107297)(0.085965)(0.216428)(0.151082) \\
t=(0.823464)(4.245865)(1.126096)(3.573824) \\
R^{2}=0.995930 \bar{R}^{2}=0.995252 S . E=0.061936 \\
F=1468.363 D W=1.253479
\end{gathered}
$$

The fitting of formula (5) is shown in Fig. 1

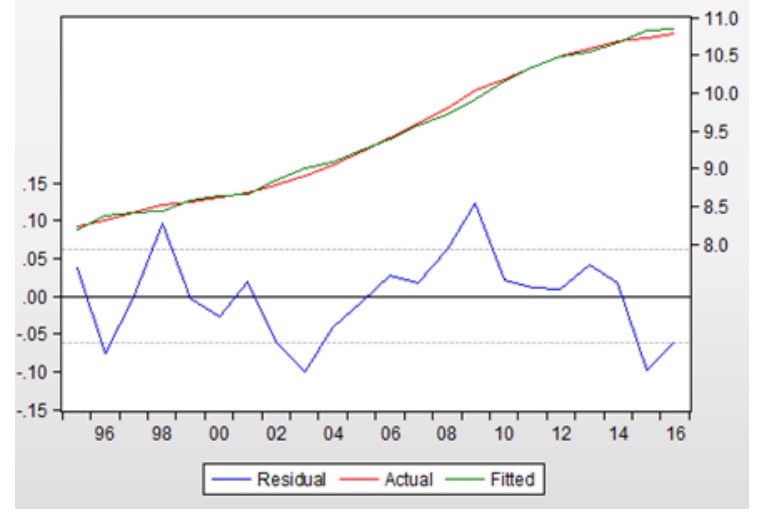

Fig. 1. Observations and fitted values

The inferential test includes a goodness-of-fit test, a general significance test ( $\mathrm{F}$ test) of the regression model, and a significance test ( $\mathrm{t}$ test) of the regression coefficient.

Firstly, the sample determination coefficient $R^{2}=0.995930$; the modified sample determination coefficient $\bar{R}^{2}=0.995252$. Since both $R^{2}$ and $\bar{R}^{2}$ are greater than 0.9 which indicates a high level, we can say that the model fits the data well.

Secondly, for F test, $F=1468.363$ and the $\mathrm{F}$ distribution table with a degree of freedom of $(3,16)$ at a $5 \%$ significance level, $F_{0.05}(3,18)=3.16$. Because $F=1468.363>3.16$, the overall model is statistically significant, that means, there exists quietly significant joint-impacts of engineering standards, employments and the investment in fixed assets in construction industry over the gross domestic product.

Finally, the test of significance, e.g. $\mathrm{t}$ test, is performed on each explanatory variable. By querying the critical value $t_{0.025}(18)=2.1009$, it is known that $t_{k}=4.245865$ and $t_{s}=3.573824$, both are greater than the critical value. Yet $t_{1}=1.126096$, it is less than the critical value. All of these indicate that the two factors, e.g. standard stock and fixed assets investment in construction industry are important explanatory variables of the total output value and then should be accepted in the model (Formula (5)); however, another factor, employments, is not so important so that it can be rejected in this model.

\section{B. Extended test of linear regression model}

Further, in order to build a robust model, we will conduct extended testing for our model. Extended testing suggests a test of robustness, in our paper includes some more sophisticated tests such as multiple collinearity testing, heteroscedasticity testing, and autocorrelation testing.

\section{1) Testing of multicollinearity}

Multicollinearity tells us there is a case in which the explanatory variables are themselves highly correlated. After $t$ test we find that the factor of employments in construction industry is not significant, and it might exists the case of multiple collinearity. Analyzing the correlation coefficients of explanatory variables, observations are shown in Table 1 as following.

TABLE I. Correlation coefficient matrix of all explanatory variables

\begin{tabular}{llll}
\hline & LN K & LN L & LN S \\
\hline LN K & 1.000000 & 0.979818 & 0.989957 \\
LN L & 0.979818 & 1.000000 & 0.984282 \\
LN S & 0.989957 & 0.984282 & 1.000000 \\
\hline
\end{tabular}

It can be found in Table 1 that correlation coefficients between the explanatory variables are very large, and they are all close to 1 . Therefore, we can conclude that there is a serious multi-collinearity. In this situation we use the Stepwise Least Squares method to solve the question. Using Eviews software, we get the result, as shown in Figure 2. It is recommended to reject $L n L$ and accept the other two explanatory variables, which are $\operatorname{Ln} S$ and $L N K$ in order, in our model (Formula (5)). 


\begin{tabular}{|c|c|c|c|c|}
\hline \multicolumn{5}{|c|}{$\begin{array}{l}\text { Dependent Variable: } G \\
\text { Method: Stepwise Regression } \\
\text { Date: } 09 / 26 / 19 \text { Time: } 21: 36 \\
\text { Sample: } 19952016 \\
\text { Included observations: } 22 \\
\text { Number of always included regressors: } 1 \\
\text { Number of search regressors: } 3 \\
\text { Selection method: Stepwise forwards } \\
\text { Stopping criterion: } p \text {-value forwards/backwards }=0.05 / 0.05\end{array}$} \\
\hline Variable & Coefficient & Std. Error & t-Statistic & Prob * \\
\hline $\begin{array}{l}\mathrm{C} \\
\mathrm{S} \\
\mathrm{K}\end{array}$ & $\begin{array}{l}2.056542 \\
0.626059 \\
0.386018\end{array}$ & $\begin{array}{l}0.442121 \\
0.131214 \\
0.084503\end{array}$ & $\begin{array}{l}4.651540 \\
4.771278 \\
4.568088\end{array}$ & $\begin{array}{l}0.0002 \\
0.0001 \\
0.0002\end{array}$ \\
\hline $\begin{array}{l}\text { R-squared } \\
\text { Adjusted R-squared } \\
\text { S.E. of regression } \\
\text { Sum squared resid } \\
\text { Log likelihood } \\
\text { F-statistic } \\
\text { Prob(F-statistic) }\end{array}$ & $\begin{array}{l}0.995644 \\
0.995185 \\
0.062371 \\
0.073913 \\
31.43837 \\
2171.274 \\
0.000000\end{array}$ & \multicolumn{2}{|c|}{$\begin{array}{l}\text { Mean dependent var } \\
\text { S.D. dependent var } \\
\text { Akaike info criterion } \\
\text { Schwarz criterion } \\
\text { Hannan-Quinn criter. } \\
\text { Durbin-Watson stat }\end{array}$} & $\begin{array}{r}9.452779 \\
0.898864 \\
-2.585306 \\
-2.436528 \\
-2.550259 \\
1.019047\end{array}$ \\
\hline \multicolumn{5}{|c|}{ Selection Summary } \\
\hline $\begin{array}{l}\text { Added S } \\
\text { Added K }\end{array}$ & & & & \\
\hline
\end{tabular}

*Note: p-values and subsequent tests do not account for stepwise selection

Fig. 2. Stepwise regression results

Then after re-establishing the multiple regression model, the new relationship is as following:

$$
\begin{aligned}
& \mathrm{LN} G=2.056542+0.626059 \mathrm{LN} \mathrm{S}+0.386018 \mathrm{LN} \mathrm{K} \\
& \mathrm{s}=(0.442121)(0.131214)(0.084503) \\
& \mathrm{t}=(4.651540)(4.771278)(4.568088) \\
& \mathrm{R}^{2}=0.995644 \bar{R}^{2}=0.995185 \mathrm{~S} . \mathrm{E}=0.062371 \\
& \mathrm{~F}=2171.274 \mathrm{DW}=1.019047
\end{aligned}
$$

\section{2) Testing of heteroscedasticity}

In regression analysis heteroscedasticity explains a situation in which the variance of the dependent variable $(G)$ varies across the levels of the explanatory variables. The reason we should know whether there is a case of heteroscedasticity because regression analysis is based on an assumption of equal variance across the levels of the independent data.

We can use the White test to perform the heteroscedasticity test. By the White test we find that:

$$
\begin{aligned}
& \chi_{0.05}^{2}(5)=11.071 \text {, at the significant level } \alpha=0.05 \\
& \text { And } \mathrm{n}^{2}=1.956900<\chi_{0.05}^{2}(5)
\end{aligned}
$$

Therefore, there is no heteroscedasticity.

\section{3) Testing of autocorrelation}

Economic activities will fluctuate in the system and be lagged over successive time intervals. Autocorrelation represents the degree of similarity between a given time series, the function can be used to detect non-randomness in data and identify an appropriate time series model if the data are not random [19].
To carry out the autocorrelation test, we can use the Lagrangian Multiplier Test. As shown in Figure. 3, at the significance level $\alpha=0.05$, results confirm that the autocorrelation hypothesis is rejected, that is, there is autocorrelation.

\begin{tabular}{llll}
\multicolumn{4}{l}{ Breusch-Godfrey Serial Correlation LM Test: } \\
\hline \hline F-statistic & 3.704892 & Prob. F(2,17) & 0.0462 \\
Obs*R-squared & 6.678275 & Prob. Chi-Square(2) & 0.0355 \\
\hline \hline
\end{tabular}

Fig. 3. BG test output

Using the Dubin Two-step Estimation method with the help of Eviews software we can estimate $\rho$ and eliminate the

\begin{tabular}{|c|c|c|c|c|c|c|c|c|c|}
\hline View & Proc & Object & Print & Name Freeze & Estimate & Forecast & \begin{tabular}{l|l|l} 
t & Stats & Res
\end{tabular} & Resids & \\
\hline \multicolumn{10}{|c|}{$\begin{array}{l}\text { Dependent Variable: G1 } \\
\text { Method: Least Squares } \\
\text { Date: 09/26/19 Time: } 22: 48 \\
\text { Sample (adjusted): } 19962016 \\
\text { Included observations: } 21 \text { after adjustments }\end{array}$} \\
\hline \multicolumn{4}{|c|}{ Variable } & Coefficient & \multicolumn{2}{|c|}{ Std. Error } & \multicolumn{2}{|l|}{ t-Statistic } & Prob. \\
\hline \multicolumn{4}{|c|}{$\begin{array}{l}\mathrm{C} \\
\mathrm{K} 1 \\
\mathrm{~S} 1\end{array}$} & $\begin{array}{l}0.435164 \\
0.182103 \\
0.933117\end{array}$ & \multicolumn{2}{|c|}{$\begin{array}{l}0.221693 \\
0.088614 \\
0.143906\end{array}$} & $\begin{array}{l}1.962907 \\
2.055015 \\
6.484191\end{array}$ & & $\begin{array}{l}0.0653 \\
0.0547 \\
0.0000 \\
\end{array}$ \\
\hline \multicolumn{4}{|c|}{$\begin{array}{l}\text { R-squared } \\
\text { Adjusted R-squared } \\
\text { S.E. of regression } \\
\text { Sum squared resid } \\
\text { Log likelihood } \\
\text { F-statistic } \\
\text { Prob(F-statistic) }\end{array}$} & $\begin{array}{l}0.982878 \\
0.980975 \\
0.049704 \\
0.044469 \\
34.85598 \\
516.6325 \\
0.000000\end{array}$ & \multicolumn{3}{|c|}{$\begin{array}{l}\text { Mean dependent var } \\
\text { S.D. dependent var } \\
\text { Akaike info criterion } \\
\text { Schwarz criterion } \\
\text { Hannan-Quinn criter. } \\
\text { Durbin-Watson stat }\end{array}$} & $\begin{array}{r}3.8 \\
0.3 \\
-3.0 \\
-2.8 \\
-3.0 \\
1.1\end{array}$ & $\begin{array}{l}895007 \\
.360356 \\
.033903 \\
884686 \\
.001519 \\
184314\end{array}$ \\
\hline
\end{tabular}
autocorrelation. The findings, as shown in Figure 4, tell us that Dubin-Watson test cannot determine whether the autocorrelation can be eliminated when given the significance level of $\alpha=0.05$, because d_L $=1.13<\mathrm{DW}=1.852567<\mathrm{d} \_\mathrm{U}=1.54$. however, the $\mathrm{BG}$ test finds that the model has no autocorrelation, as shown in Figure 5.

Fig. 4. Dubin two-step estimation method estimation results

4) The modified model

After extended tests for this multiple linear regression model, the moderated model can be determined as following:

$\mathrm{LN} \mathrm{G}=0.435164+0.933117 \mathrm{LN} \mathrm{S}+0.182103 \mathrm{LN} \mathrm{K}$

$$
\begin{gathered}
\mathrm{s}=(0.221693)(0.143906)(0.088614) \\
\mathrm{t}=(1.962907)(6.484191)(2.055015) \\
\mathrm{R}^{2}=0.982878 \bar{R}^{2}=0.980975 \mathrm{~S} . \mathrm{E}=0.049704 \\
\mathrm{~F}=516.6325 \mathrm{DW}=1.184314
\end{gathered}
$$




\section{DISCUSSIONS}

\section{A. The explanations of Multicollinearity}

As shown in Figure 1 and Table 1, there exists multicollinearity in Equation (5), i.e. the existence of such a high degree of correlation between supposedly independent. Because of some characteristics of construction products, such as single production, complex processing, etc., construction reveals its nature of a labor-intensive industry. Partly as a result of these characteristics, multicollinearity will occur when labor is being used to estimate the dependent variable to a large extent.

\section{B. The coefficients of independent variables}

In Equation (5), we will find that the sum of coefficients of Ln $\mathrm{K}$ and $\mathrm{Ln} \mathrm{L} \mathrm{(e.g.} \alpha$ and $\beta$ ) is less than 1.0. This means that returns to scale are decreasing.

And in Equation (7), the coefficient of $\mathrm{Ln} \mathrm{S}$ is much larger than the coefficient of $\operatorname{Ln~K~}(0.933117>0.182103)$. The findings testify that standards are much more important over capital in the promotion of construction growth, hence highlighting that it is a favorite policy to develop standards in priority.

\section{CONCLUSION AND SUGGESTION}

\section{A. Conclusion}

As a pillar industry of the national economy, the construction industry plays an important role in both domestic development and foreign investment. Building standards are also critical throughout the development of the construction industry. This paper uses China as an example to testify the importance of standards in the economic growth in construction industry. Hereby we introduce the extended CobbDouglas production function to measure the relationship between engineering standards and the economic growth in this industry. The results show that there is a significant positive relationship between engineering standards and construction economy when based data from 1995 to 2016 in China. The empirical analyses tell us that when capital investment increases by $1 \%$, output from construction industry will grow by $0.182 \%$; comparing with the effects of capital investment, when standards add by $1 \%$, and output from this industry will gains additional $0.933 \%$ product. This shows that engineering standards have a strong driving force for the economic growth in construction industry.

\section{B. Suggestion}

The above research suggests that engineering standards play an important role in construction industry. Construction can supply many employments for the economy, yet as a kind of production factor, labor will contribute little to the competitiveness of this industry. Contrasting with capital investment, standards can seem as an expression of technical progress, can much more significantly boost construction economy. For developing countries, it might be a pragmatic way to draw up and enact more standards to grow construction industry, and then push the economy.

\section{ACKNOWLEDGMENT}

This work is supported by the National Natural Science Foundation of China (NSFC) under Grant 71463061 (Project Title: Study on Participatory Appraisal Mechanism for Local Government Public Works). The authors extend their great gratitude to NSFC for the sponsorship.

\section{REFERENCES}

[1] National Standards Committee. "National Standard Full Text Disclosure System [EB/OL],"2019. (http://www.gb688.cn/bzgk/gb/index)

[2] China National Institute of Standardization, "China Standardization Development Research Report," China Standard Press, 2006.

[3] B. N. Rosen, S. P. Schnaars, D. Shani. "A comparison of approaches for setting standards for technological products," Journal of Product Innovation Management, vol. 5, 1988, pp. 129-139.

[4] P. D. Curran. "Standard-Setting Organizations: Patents, Price Fixing, and Per Se Legality," The University of Chicago Law Review, vol. 3 , 2003, pp. 983-1009.

[5] L. Ye, C. Yan. "Technical Standards-New Weapons of Paten Warfare," Research and Development Management, vol. 2, 2003, pp. 54-59.

[6] R. P. Harette, H. E. Marshall. "UNIFORMAT II elemental classification for building specifications, cost estimating, and cost analysis," US Department of Commerce, Technology Administration, National Institute of Standards and Technology, 1999.

[7] A. Jungmittag, K. Blind, H. Grupp. "Innovation, standardization and the long-term production function: a cointegration analysis for Germany 1960-1996," 1999.

[8] K. Blind, A. Jungmittag "Trade and the Impact of Innovations and Standards: The Case of Germany and the UK," Applied economics, vol 12, 2005, pp. 1385-1398.

[9] Z. Liu. "Technological Innovation, Technical Standards and Economic Development," China Standard Press, 2005.

[10] X. Yu. "Standardization and Economic Growth," China Standard Press, 2008

[11] C. A. F. Riillo. "Profiles and motivations of standardization players," International Journal of IT Standards and Standardization Research (IJITSR), vol. 2, 2013, pp. 17-33.

[12] G. M. P. Swann. "The economics of standardization: An update," Report for the UK Department of Business, Innovation and Skills (BIS), 2010.

[13] C. Wang. "Research on the impact of engineering construction standardization on national economy," Beijing Jiaotong University, 2009

[14] X. Wu. "Research on the evaluation method of the impact of engineering construction standardization on national economy," Beijing Jiaotong University, 2010.

[15] X. Liang, F. Lu, D. Li, F. Yang. "An Empirical Study of the Impact of Engineering Construction Standards on China's Economic GrowthBased on Cointegration Theory, Granger Causality Test and Ridge Regression," Systems Engineering Theory and Practice, vol. 5, 2010. pp. 841-847.

[16] K. Blind. "The Economics of Standards: Theory, Evidence, Policy," Cheltenham: Edward Elgar Publishing Limited. 2004.

[17] M. Patricia. Hillebrandt. (2000). "Economic Theory and the Construction Industry," London: Palgrave Macmillan. 